\title{
An approach to death education
}

\begin{abstract}
Death and dying are still taboo subjects in today's society. In most Western countries, people die principally in hospitals, surrounded by healtand high technology but without a true humanization of care. This transfer of death from home to hospitals, which began in the $60 \mathrm{~s}$ of the last century, has brought social and cultural consequences to the way we deal with the end of life. We will have resort to the work of some experts, such as Elisabeth Kübler-Ross (1926-2004), to consider the need for death education.
\end{abstract}

Keywords: death, dying, education
Volume 4 Issue 6 - 2019

\author{
João Carlos Macedo \\ Adjunct Professor, Nursing School, University of Minho, Portugal
}

Correspondence: João Carlos Macedo,Adjunct Professor, Nursing School, University of Minho, Ed.4 - Campus Gualtar 47I0-057 Braga - Portugal,Tel, 25360I303, Email jmacedo@ese.uminho.pt

Received: December 17, 2019 | Published: December 27, 2019

\section{The death- denying society}

Although there is already more discussion about human death these days, it can be said that it is still a taboo theme. According to Barros de Oliveira, "[...] all the taboos have fallen like sex, but death today is more than ever forbidden to be shown as an obscene or pornographic thing [...]". ${ }^{1}$ This death denial is inherent in the very performance of today's society, since" [...] technically it is admitted that we can die and take steps in life to preserve ours from misery. But truly, deep within ourselves, we do not feel mortals ". ${ }^{2}$ The very "place" or "places" where one usually dies today, so different from the times it once was, now contrubute to this feeling of unfamiliarity with death. Death as life event went from the family domain to the domain of health technicians. There were generations when the person died at home, said goodbye to the family, solved the last commitments in life and everyone watched this event in a deeply natural settings. Today, and since the 1960s, progress in the area of resuscitation and medical intensivism led to hospitalization of death. In some countries, these transformations were so evident that today two thirds of the British die in the hospitals and $80 \%$ of deaths in the United States occur in various health units. ${ }^{3}$ This is a trend that also occurs in Portugal, where approximately $60 \%$ of deaths occur in hospital units. ${ }^{4,5}$ This social transformation of the place of death led to a progressive forgetting of the notion of death in the community context and even denying it: [...] the reigning materialism and hedonism do not support that the thought of death will disturb a growing consumerism of goods and pleasures, death is seen as a fact only from a biological standpoint and not as a deeply human reality. ${ }^{1}$ This "concealed" death - term used by Ivan Illich - , ${ }^{6}$ and hospitalized has repercussions on the health care of the end-of-life person, family members and even with health technicians who deal with terminally ill patients daily. Today is consensual and several authors who have carried out field studies, have stated that experience of suffering and loss may be adverse to the proper functioning of the immune system, accentuating the risk of disease and eventually rushing to death. Like examples of problems with people who have lost loved ones, this situation also points to the increased use of alcohol, drugs, the emergence of depression and inability to work. It should also be noted that healthcare may experience various symptoms of stress if they are permanently caring for terminally ill people. All these facts lead us to reflect on the death-health binomial and the current uprooting deatin community life. People die in the hospital, alone, surrounded by white coats, and often they cannot face and introduce death into their horizons because they never had a chance to discuss this during their life. On the other hand, family members and friends, also find themselves in na awkward positionfor not including death as an integral part of life, and can develop prolonged and life-threatening grief processes disease. In contact with terminally ill patients and family, there is currently a certain degree of distancing from the patient, a certain disorientation of the family and even a coldness in the attitudes of certain professionals when faced with death.

\section{Death education by the work of elisabeth kübler-ross}

In the path of tanatology, there is a name that is a classic reference in this field: Elisabeth Kübler-Ross (1926-2004). Kübler- Ross was a swiss psychiatrist, who later became a US citizen,.She soon became interested in working with those at the end of life, beginning their investigations in the late sixties of the last century. Since this time, in addition to following up with several hundred people at the end of their lives,she has produced over a dozen books dedicated to reflection on death and accompaniment at the end of life. Despite all the controversy about her work in the Scientific world, ${ }^{7,8}$ her perspective leads us to the need to integrate death into life, making it clear that the dying are our best masters of the meaning of death and life. On the other hand, death is considered, not as a failure of the medical forum, but as a natural and predictable process. In addition to alerting us to the need for greater awareness of one's own death, Kübler-Ross thought that accompanying the person at the end of his life would change certainly our perception of mortality. Driven by the author's thought I found that this inclusion of death in the discourse should undergo a death education in order to be more "naturalness" and as an inescapable fact of life. It is concluded that Kübler-Ross was a legitimate advocate of the "fall of the wall" of death in society. The concealment of death in social life, the hidden place, has led to the current situation of the person being unable to deal with a "natural" form of end of life. As Santos tells us in this regard: "Hiding suffering, dying and death is not healthy for a society. [...] Hardly a society that ostracizes the idea of death learns to care for and respect their elderly 
or understand and respect the grief pain felt by someone who has lost a friend or family member". ${ }^{9}$ Now Kübler-Ross has fought vehemently against this social problem, and throughout her life. In this work, the warning for a greater social awareness of death is clearly evident. Just pointing out the On Death and Dying seminars and the workshops she conducted, we have already two clear examples of contributions to social awareness of death. Her great merit was to break the conspiracy of silence around the death, which was installed in the social environment in general and among healthcares in particular. For her, any important aspect of people's lives should be the subject to attention and discussion, whether it was birth, illness or death. Just in this way it would be easier, or less painful, to deal with many of the problems people have when they lose someone or are the victims of deadly disease, being viewed as part of life. From the time of her childhood, through his medical training and, with more from the sixties, when she passed Billings through Hospital directing the On Death and Dying seminars, Kübler-Ross embarked on a life-oriented death issues, rather to bring it closer and accompany those in the final phase of life. In his performance, we come across a constant note: to meet those who are die and acting there in the most empathetic way possible. It is this fundamental attitude that drives her to not forget the patient's family or the specificity of the death in the children, trying to also make its humanitarian contribution to AIDS patients. It was this fundamental idea of not to be overcome by the fear of death, whatever it may take, let alone abandoning the dying, which led Kübler-Ross to perform in several areas of dying, trying to bridge the educational gap about death in our societies. Although some of her conclusions do not comply with all the Scientific rules, her work has created conditions for others to realize the problems in the tanatological field and at the same time, also contributed to a greater empowerment of the terminally ill patient, In other words, it can be said that KüblerRoss's work has helped the terminally ill patient gain greater credibility with society and acquire a new status with health professionals.

By drawing attention to the major problems that were present in the care of terminally ill patient, Kübler-Ross denounced the dehumanization of this and stated that the end-of-life person retains all his dignity, can we learn much from him if we approach her bed and follow her to the end. It is here, in this follow-up, that KüblerRoss intends to sensitize the professionals in particular, and society in general, for the special needs of the patient at the end of life. In this sense, the author tries, as I mentioned earlier, through her work, to break social silence about death, using the terminally ill patients, their stories to make society aware of its most pressing problems. Yet, Kübler-Ross has not forgotten another important facet, closely related to the patient in terminal phase, the accompanying needs of family and friends. Let's say there's a triple front in Kübler-Ross breaking of the taboo of the death and reintroduce the theme in social discourse: a) denunciation of the state of social death denial; b) awareness of the needs of the terminally ill patient; c) awareness of the needs of relatives and friends of the terminally ill patient. In addition, Kübler-Ross, through his seminars, workshops he gave and the many lectures he gave, was spreading these ideas, contributing to a more humanizing view of the terminally ill patient and at the same time boosting end-of-life health care through the birth of palliative care. Dennis Klass, Professor of Religious Studies at Webster University, St. Louis, Missouri, and former assistant of Kübler-Ross at the On Death and Dying seminars at the University of Chicago, supports this idea by stating that:

"The five stadiums that Kübler-Ross talks about in his first book, in which warns of the need to listen to those who are dying - whose life experiences can be of great use to the current society, denying death - was clearly a factor in the motivation for the founding of many rear hospitals, and for the establishment of support programs for the dying and their family and friends". ${ }^{10}$

The objective of palliative treatment is to achieve the best possible quality of life for the patient and his family. ${ }^{11}$ From this perspective, it is clear that the work of KüblerRoss has been a driving force behind the development of palliative care, especially in the United States. States of America. The author herself corroborates the idea by stating that: "In the United States, the Hospice of New Haven in Connecticut was the first one that opened it doors to a home care program in order to give people the total patient care that is necessary when cure, active treatment, and prolongation of life are no longer the goal. Since the opening of the Hospice in New Heaven, we have been able to facilitate and encourage 55 other places in the United States to develop a hospice, and it is a rare state that does not have such a facility at least in the planning stages". ${ }^{12}$ I can say, in a final and brief analysis, that Kübler-Ross was a pioneer because sought in various ways to introduce death education, which I consider to be a facet of health education. As Charles Corr, Clyde Nabe and Donna Corr tell : "With Kübler-Ross (1969), death education seeks to show its relevance in all of these ways: to the client who is coping with dying or bereavement; to the helper in his or her work-related role; and to the helper as a person in his or her own right. ${ }^{13}$ Thus, it is concluded that their entire route tends to create conditions for the death and those in the final stages of life are the subject of discussion, attention and, above all, truly incorporated into social life. The author intends to generate a more healthy not to reject death but to see it as a part of life. Contact with death experiences and the inclusion and discussion of death from childhood will contribute to see as an integral part of life and will certainly help in the growth and maturation of the person. ${ }^{14}$ As KüblerRoss wrote in her autobiography: "My parents did not shield me from life and death as it happened naturally, which allowed me to absorb the different circumstances as well the people's reactions ". ${ }^{15}$ I can summarize this with a sentence:" If it is natural to die, because it is not natural to educate about and to death, speak of one's own and others' death, and teach (and learn) live and well die? It will not be possible a pedagogy of death, which could we call tanatological education? The answer is no only such education is possible but also necessary for integral education. ${ }^{1}$

\section{Death education: next chapters}

Following the work Kübler-Ross and others experts began in the 1960 s, there is still a need to (re) introduce death and dying into social discourse. So, we have listed some death education practices that may apply in many western countries:

1. within the strategies that need to be implemented, the most urgent would be to introduction of the theme of death in school curricula, as a cross-cutting subject, from the first years of school. This would necessarily help the integration of death from an early age. This idea is not original, since in other countries, such as the United States of America, Israel, Canada and Australia, there are some cases the integration the theme of death in the school curriculum. ${ }^{16}$

2. there is also an imperative need to increase the number of hours of training about death and dying in the curriculum of the future health professionals. The medical and nursing schools still have a few hours to study death and dying, ${ }^{17}$ 
3. Implement death education programs to health professional that are daily coping with dying patients; ${ }^{18,19}$

4. Encouraging the formation of volunteer groups willing to accompanying terminally ill patients would be an interesting way of bringing people together of the death process, would help in identifying the needs of the sick and, above all, would break the silence that surrounds death;

5. Create short-course on death and dying for adults could help to integrate death into life, lessen fear and anxiety;

6. In countries who the living will or advance care planning is legal, they can empower the citizen with its elaboration. In other words, there is need for policies to disseminate the living will, especially in older population, to exercise autonomy and to prevent futility treatments. Talking about the end of life with a trusted person is the first step to being able to write down the wishes / desires to be fulfilled when the person is at the end of life;

7. Finally, in some countries, the decriminalization of assisted death is being discussed (as is the case of Portugal, which will have a vote in Parliament in 2020). This is an exclusive opportunity to discuss the end of life in society. Regardless of the outcome, the educational process occurs when the community quits taboos and faces the problem.

It is a challenge for all to make efforts to death education is a reality and not just a rhetoric of some or simple mere intention of others. The sooner conditions are created for an effective death education may occur, we will more easily face the end of life with some "naturalness". Probably many health problems will diminish if we view death as a natural and inevitable fact of every human being's life.

\section{Acknowledgments}

None.

\section{Conflicts of interest}

The author declare have no conflict of interest about the publication of this paper.

\section{References}

1. Barros de Oliveira J.H. Viver a morte - abordagem antropológica e psicológica. Coimbra: Livraria Almedina; 1998.
2. Ariès P. Western attitudes toward death from the middle ages to the presente. Baltimore: The Johns Hopkins University Press; 1975.

3. Nuland SB. How we die:reflections of life's chapter final. New York: Vintage Books. 1993.

4. Machado MC. A morte e o morrer em Portugal. Coimbra: Almedina; 2011

5. Gomes B1, Sarmento VP, Ferreira PL, et al. Epidemiological study of place of death in Portugal in 2010 and comparison with the preferences of the portuguese population. Acta Médica Portuguesa. 2013;26(4):327334.

6. Illich I. Limits to medicine. medical nemesis: the expropriation of health. New York: Random House; 1976

7. Corr CA. Coping with dying:lessons that we should and should not learn from the work of Elisabeth Kübler-Ross. Death Studies. 1993;17:69-83.

8. Chaban MCG. The life work of Dr. Elisabeth Kübler-Ross and its impact on the death awareness movement. NewYork/Ontario: Edwin Mellen Press; 2000.

9. Santos LF. Euthanasia: to be able to love life to the end ?.Interacções. $2003 ; 4: 25-58$.

10. Klass D, Kübler-Ross, Elisabeth. In: Howarth G \& Leaman O, editors. Encyclopedia of death and dying. New York: Routledge; 2001: 316-317.

11. http://www.who.int/cancer/palliative/definition/en

12. Kübler-Ross E. To live until we say good-bye. New Jersey: PrenticeHall; 1978.

13. Corr CA, Nabe CM, Corr DM. Death and dying, life and living. California: Brooks. Cole Publishing Company; 1994.

14. Kübler-Ross E. On death and dying. New York: Touchstone; 1969.

15. Kübler-Ross E. The wheel of life: a memoir of living and dying. New York: Touchstone; 1997

16. Clark V. Education. In: Howarth G, Leaman O, editors. Encyclopedia of death and dying. New York: Routledge; 2001:192-195

17. Dickinson G. End-of-life and palliative care issues in medical and nursing schools in the United States. Death Studies. 2007; 31:713-726.

18. Dadfar M, Lester D. The effectiveness of $8^{\mathrm{a}}$ model death education on the redution of death depression a preliminar study. Nursing Open. 2009;00:1-5.

19. Cui J. What do nurses want to learn from death education? A survey of their needs. Oncology Nursing Forum. 2011;38 (6):E402-E408. 